\title{
PENGARUH SISTEM INFORMASI AKUNTANSI TERHADAP EFEKTIVITAS PENGENDALIAN PIUTANG DAN KOLEKTABILITAS PIUTANG TAK TERTAGIH PADA BPRS BHAKTI SUMEKAR CABANG PAMEKASAN
}

\author{
Arifuddin \\ ariefluca1995@gmail.com \\ Agus Sugiono \\ agusuimak@fe.uim.ac.id \\ Fakultas Ekonomi Universitas Islam Madura
}

\begin{abstract}
The purpose of this study is to determine whether the sales accounting information system influences the effectiveness of receivables control and the effectiveness of collectibility of uncollectible receivables in BPRS Bhakti Sumekar, Pamekasan Branch. This type of research uses descriptive quantitative methods. Data collection is done using a questionnaire. From the results of the study it is known that there is a significant relationship between accounting information systems and the effectiveness of accounts receivable control and collectability of uncollectible accounts. The simple correlation coefficient $(R)$ for the effectiveness of receivables control is 0.826 , which means that the accounting information system has a close or strong relationship to the effectiveness of accounts receivable control, which is 0.826 or $82.6 \%$. While collectibility of uncollectible accounts of 0.847 means that the input variable consisting of accounting information systems has a close or strong relationship to collectability of uncollectible accounts of 0.847 or $84.7 \%$. The coefficient of determination for the effectiveness of accounts receivable control is obtained value $\left(\mathrm{R}^{2}\right)=0.683$ which means that $68.3 \%$ of the effectiveness of the control of accounts receivable can be explained by the accounting information system while the remaining $31.7 \%$ is influenced by other variables outside the model studied. uncollectible obtained value $\left(\mathrm{R}^{2}\right)=0.717$ which means that $71.7 \%$ collectability of uncollectible accounts can be explained by accounting information systems while the remaining $28.3 \%$ is influenced by other variables outside the model studied.
\end{abstract}

Keywords: Accounting Information System, Accountability Control Effectiveness, Collectability of Uncollectible Receivables 


\section{ABSTRAK}

Tujuan penelitian ini untuk mengetahui apakah sistem informasi akuntansi penjualan berpengaruh terhadap efektivitas pengendalian piutang dan efektivitas kolektabilitas piutang tak tertagih di BPRS Bhakti Sumekar Cabang Pamekasan. Jenis penelitian ini menggunakan metode kuantitatif deskriptif. Pengumpulan data dilakukan dengan menggunakan kuesioner. Dari hasil penelitian diketahui bahwa terdapat hubungan yang signifikan antara sistem informasi akuntansi dengan efektivitas pengendalian piutang dan kolektabilitas piutang tak tertagih. Nilai koefisien korelasi sederhana (R) untuk efektivitas pengendalian piutang sebesar 0,826 artinya bahwa sistem informasi akuntansi mempunyai hubungan yang erat atau kuat terhadap efektivitas pengendalian piutang yaitu sebesar 0,826 atau $82,6 \%$. Sedangkan kolektabilitas piutang tak tertagih sebesar 0,847 artinya bahwa variabel input yang terdiri sistem informasi akuntansi mempunyai hubungan yang erat atau kuat terhadap kolektabilitas piutang tak tertagih sebesar 0,847 atau $84,7 \%$. Nilai koefisien determinasi untuk efektivitas pengendalian piutang diperoleh nilai $\left(\mathrm{R}^{2}\right)=0,683$ yang berarti bahwa $68,3 \%$ efektifitas pengendalian piutang dapat dijelaskan oleh sistem informasi akuntansi sedangkan sisanya 31,7\% dipengaruhi oleh variabel lain diluar model yang diteliti.Hasil perhitungan untuk kolektabilitas piutang tak tertagih diperoleh nilai $\left(\mathrm{R}^{2}\right)=0,717$ yang berarti bahwa 71,7 \% kolektabilitas piutang tak tertagih dapat dijelaskan oleh sistem informasi akuntansi Sedangkan sisanya 28,3\% dipengaruhi oleh variabel lain diluar model yang diteliti.

Kata kunci: Sistem Informasi Akuntansi, Efektifitas Pengendalian Piutang, Kolektabilitas Piutang Tak Tertagih

\section{PENDAHULUAN}

Sejak tahun 2010, persaingan bank semakin ketat degan hadirnya bank-bank asing yang membuka kantor di idonesia atau dengan bergabung dengan bank lokal. Persaingan terjadi karena nasabahsemakin pandai memilih bank yang aman dan memiliki pelayanan yang berfariasi, sehingga bank berlomba-lomba meningkatkan teknologi informasi agar dapat memberikan layanan jasa yang memuaskan. Menigkatnya persaingan antar bank, menuntut setiap bank memberikan pelayanan yang memuaskan kepada nasabah. Salah satu pelayanan yang diberikan tersedianya data dan informasi yang cepat dan akurat (Ismail 2010).

Meningkatkan permintaan pinjaman kredit atau pinjaman uang yang di ajukan oleh nasabah/masyarakat (Debitur) akan menyebabkan investasi dalam piutang meningkat. Peningkatan investasi dalam piutang menyebabkan modal kerja yang tertanam dalam piutang akan semakin besar. Perusahaan yang baik adalah perusahaan yang dapat mengendalikan seluruh kegiatan didalam perusahaan sehingga tujuan perusahaan dapat dicapai sesuai dengan apa yang direncanakan. Piutang Usaha sebagai salah satu aktiva lancar perusahaan, merupakan aktiva yang penting karena secara tidak langsung dapat menunjukkan besarnya pendapatan yang diterima, pos piutang timbul karena pembiayaan kredit. Perusahaan juga perlu mengambil tindakan untuk terkait dengan adanya piutang, dikhawatirkan perusahaan akan mengalami kerugian yang diakibatkan piutang tak tertagih. Oleh karena itu perlu diadakan suatu pengendalian yang efektif sehingga tindakan-tindakan kecurangan terhadap piutang usaha dapat dikurangi.

Permasalahannya adalah bagaimana agar pengendalian piutangdan kolektabilitas piutang tak tertagih dapat berfungsi dengan efektif, untuk mengatasinya diperlukan sistem informasi akuntansi yang memadai, sehingga dapat membantu pimpinan perusahaan dalam 
menjalankan usahanya. Sistem informasi akuntansi diperlukan untuk menyediakan bukti pencatatan, bukti piutang, dan pelaporan yang memadai atas seluruh kegiatan perusahaan, sehingga dapat disajikan informasi yang berguna bagi kepentingan pimpinan dalam pengambilan keputusan.

Sistem informasi akuntansi dibuat dengan tujuan untuk dapat mengontrol kolektibilitas piutang tak tertagih dan mengendalikan aktivitas penjualan. Hal ini perlu karena penjualan dapat mengakibatkan kesalahan pada sistem atau tingkat kecurangan yang disengaja akibat kelemahan sistem itu sendiri. Pengendalian ini harus bisa menjamin kebijakan dan pengarahan-pengarahan bagi pihak manajemen dan sebagai alat untuk mengimplementasikan keputusan dan mengatur aktivitas perusahaan khususnya bagian penjualan dan bagian akuntansi untuk dapat mencapai tujuan perusahaan serta upaya perlindungan terhadap seluruh sumber daya perusahaan dari kemungkinan kerugian yang diakibatkan oleh kesalahan atau kelalaian pemrosesan data-data penjualan, selain hal tersebut kerugian yang ditimbulkan juga pada piutang yang tak tertagih berpengaruh terhadap tujuan utama peruasahaan dan kelangsungan hidup suatu perusahaan.

Siregar (2016) meneliti tentang Pengaruh Sistem Informasi Akuntansi Penjualan terhadap Efektifitas Pengendalian Piutang pada PT Edwindo. Hasil penelitian menunjukan bahwa sistem informasi akuntansi penjualan sudah baik, begitu pula dengan efektivitas pengendalian piutang. Hasil penelitian secara kuantitatif menunjukkan terdapat pengaruh sistem informasi akuntansi penjualan terhadap efektivitas pengendalian piutang. Untuk meningkatkan efektivitas pengendalian piutang, perusahaan sebaiknya meingkatkan kompetensi sumber daya manusia yang dimiliki perusahaan.

Tujuan dari penelitian ini adalah: (1) Apakah sistem informasi akuntansi berpengaruh terhadap efektivitas pengendalian piutang di BPRS Bhakti Sumekar Cabang Pamekasan (2). Apakah sistem informasi akuntansi berpengaruh terhadap efektivitas kolektabilitas piutang tak tertagih di BPRS Bhakti Sumekar Cabang Pamekasan.

\section{TINJAUAN TEORI}

\section{Penelitian terdahulu}

Rahmawati (2015) meneliti tentang Pengaruh Sistem Informasi Akuntansi Penjualan Terhadap Efektivitas Pengendalian Piutang Pada PT. Permata Finance Samarinda. Jenis penelitian ini adalah penggabungan antara penelitian kualitatif dan kuantitatif, teknik analisis data kuantitatif menggunakan regresi lienear sederhana, koefisien korelasi pearson product moment, dan koefisien determinasi. Sedangkan, teknik analisis data kualitatif menggunakan reduksi data, penyajian data dan menarik kesimpulan. Hasil penelitian secara kualitatif menunjukkan bahwa sistem informasi akuntansi penjualan sudah baik, begitu pula dengan efektivitas pengendalian piutang sudah baik, dan hasil penelitian secara kuantitatif menunjukkan besarnya pengaruh signifikan sistem informasi akuntansi penjualan terhadap efektivitas pengendalian piutang.

Christian dan victorina (2015) meneliti tentang Analisis Pengedalian Internal Piutang Usaha Pada Developer Grand Kawanua International City. Jenis penelitian ini adalah deskriptif kualitatif pengumpulan data yang dilakukan dengan cara observasi, wawancara, dan dokumentasi. Hasil penelitian menunjukkan pengendalian intern piutang telah berjalan dengan baik, dikarenakan tidak terdapatnya kesalahan yang signifikan pada pencatatan piutang dan penagihan juga berjalan dengan lancar. Manajemen perusahaan sebaiknya mengurangi penerimaan piutang lewat kasir secara tunai untuk menghindari 
resiko kehilangan dan pencurian, sebaiknya perusahaan menggunakan sistem baru yang mengikuti perkembangan zaman.

Maulana (2016) meniliti tentang Pengaruh Sistem Informasi Akuntansi Penjualan Terhadap Efektivitas Kolektibilitas Piutang Tak Tertagih Pada PT Colombus Show Room Majalengka. Jenis penelitian ini merupakan jenis kuantitatif deskriptif, teknik analisis data menggunakan analisis koefisien korelasi sederhana, analisis koefisien determinasi dan uji hipotesis. Hasil penelitian menunjukkan bahwa sistem informasi akuntansi penjualan termasuk kedalam kategori baik. Untuk efektivitas kolektibilitas piutang tak tertagih termasuk kedalam kategori baik. Sistem informasi akuntansi penjualan berpengaruh positif terhadap kolektibilitas piutang tak tertagih sehingga hipotesis yang diajukan terbukti kebenarannya.

\section{Sistem Informasi Akuntansi}

Setiap perusahaan menerapkan akuntansi sebagai alat komunikasibisnis. Akuntansi merupakan proses pencatatan (recording), pengelompokkan (classifying), perangkuman (summarizing), dan pelaporan (reporting) dari kegiatan transaksi perusahaan. Tujuan akhir dari kegiatan akuntansi adalah penerbitan laporan-laporan keuangan. Laporan-laporan keuangan tersebut merupakan suatu informasi (Jogiyanto, 1997:47).

Menurut Jusup (2011) sistem informasi akuntansi adalah mengumpulkan dan mengolah data transaksi serta mengomunikasikan informasi keuangan kepada para pengambil keputusan. Sistem informasi akuntansi terdiri tas bukti dokumen transaksi, alatalat pencatatan, laporan-laporan, dan prosedur-prosedur yang digunakan suatu perusahaan untuk mencatat transaksi-transaksi serta melaporkan hasil-hasilnya. Perancangan suatu sistem informasi akuntansi meliputi tiga tahapan. Pertama, mengenal dokumen bukti transaksi yang digunakan perusahaan, baik mengenai banyaknya maupun jumlah-jumlah rupiahnya, serta data penting lain yang berkaitan dengan transaksi perusahaan. Kedua, mengelompokkan dan mencatat data yang tercantum dalam catatan-catatan akuntansi. Ketiga, meringkas informasi akuntansi yang tercantum dalam catatan-catatan akuntansi menjadi laporan-laporan untuk manajemen dan pihak-pihak lain yang berkepentingan.

Sistem informasi akuntansi diklasifikasikan menjadi dua yaitu: (1) Sistem informasi akuntansi manual (2) Sistem informasi akuntansi berbasis komputer. Sistem informasi akuntansi manual merupakan proses pencatatandengan menggunakan dokumen, jurnal, dan buku besar (Hall, 2007). Dokumen terbagi menjadi tiga jenis, yaitu dokumen sumber, dokumen produk, dan dokumen perputaran. Dokumen sumber adalah dokumen yang diciptakan pada awal transaksi melalui peristiwa ekonomi. Dokumen produk adalah dokumen hasil dari pemrosesan transaksi, bukan dokumen yang memicu proses. Dokumen perputaran adalah dokumen produk darisatu sistem yang menjadi dokumen sumber dari sistem lainnya.

Sistem informasi akuntansi berbasis komputer merupakan proses pencatatan dengan menggunakan bantuan komputer. Catatan akuntansi dalam sistem berbasis komputer disajikan dalam empat jenis file magnetis,yaitu (Hall, 2007) : (a) File master (master file). File master umumnya berisi data akun. Buku besar umum dan bukubesar pembantu adalah contoh dari file master. Nilai data dalam filemaster diperbarui dari transaksi (b) File transaksi (transaction file. File transaksi adalah file sementara yang menyimpan catatan transaksiyang akan digunakan untuk mengubah atau memperbarui data dalamfile master. Contohfile transaksi misalnya pesanan penjualan,penerimaan persediaan, 
dan penerimaan kas (c) File referensi (reference file). File referensi menyimpan data yang digunakan sebagai standar untukmemproses transaksi. File referensi meliputi daftar harga yangdigunakan untuk menyiapkan faktur pelanggan, daftar pemasok yangdiotorisasi, jadwal karyawan, dan file kredit pelanggan untukpersetujuan penjualan kredit (d) File arsip (archive file). File arsip berisi catatan transaksi masa lalu yang dipertahankan untukreferensi di masa depan. File arsip meliputi jurnal, informasi penggajian periode sebelumnya, daftar nama karyawan sebelumnya, catatantentang akun yang dihapus, dan buku besar periode sebelumnya.

\section{Pengendalian Piutang}

Prosedur pengendalian piutang erat hubungannya dengan pengendalian penerimaan kas disatu pihak dan pengendalian dipihak lain.Piutang merupakan mata rantai diantara keduanya. Ditinjau dari cara pendekatan manajen preventif, maka ada tiga bidang pengendalian yang umum dimana dapat diambil tindakan untuk mewujudkan pengendalian piutang. Maulana (2000:418) terjamahan dari Wilkinson menyebutkan ketiga bidang itu adalah: (1) Pemberian kredit dagang. Kebijakan kredit dan syarat penjualan harus tidak menghalangi penjualan kepada para pelanggan yang sehat keadaan keuangannya, dan juga tidak boleh menimbulkan kerugian yang besar karena adanya piutang sanksi yang berlebihan. (2) Penagihan. Apabila telah diberikan kredit, harus dilakukan usaha untuk memperoleh pembayaran yang sesuai dengan syarat penjualan dalam waktu yang wajar. (3) Penetepan dan penyelenggaraan pengendalian intern yang layak meskipun prosedur pemberian kredit dan penagihan telah diadministrasikan dengan baik ataupun dilakukan dengan cara wajar, tidak menjamin adanya pengendalian pengendalian piutang, yaitu tidak menjamin ataupun dapat memastikan bahwa semua penyerahan memang difaktur, atau difaktur sebagaimana mestinya, kepada para pelanggan dan bahwa penerimaan benar-benar masuk kedalam rekening bank perusahaan sehingga harus diberlakukan suatu sistem pengendalian yang memadai.

\section{Kolektabilitas Piutang Tak Tertagih}

Muchdarsyah dalam Moermahadi (2006) menjelaskan kolektibilitas adalah tingkat pengembalian kredit kepada perusahaan yang memberikan pinjaman berupa uang atau surat berharga. Andreas (2006) suatu piutang tak tertagih adalah kerugian pendapat yang memerlukan melalui ayat pencatatan yang tepat di dalam perkiraan penurunan dalam perkiraan harta piutang dan penurunan yang berkaitan dalam labadan ekuitas pemegang saham. Secara umum, suatu piutang diindikasikan sebagai piutang tak tertagih apabila telah jauh melewati tanggal jatuh temponya. Piutang yang telah ditentukan sebagai piutang tak tertagih merupakan suatu kerugian yang harus dicatat sebagai beban (expanse) yaitu beban piutang tak tertagih (bad debt expanse) dalam laporan laba rugi. Semua penghapusan ini harus dicatat dengan tepat dan diteliti karena berhubungan langsung dengan laporan keuangan yang digunakan manajemen dalam mengambil keputusan.

Penjualan secara kredit akan menimbulkan keuntungan sekaligus kerugian. Orang yang tidak dapat membayar sekarang akan melakukan pembelian secara kredit. Penerimaan dan keuntungan perusahaan akan meningkat karena penjualan meningkat, tapi kerugian yang dialami oleh perusahaan meningkat pula karena meningkatnya jumlah piutang yang tidak dapat ditagih. Informasi akuntansi menjadi salah satu dasar 
pengendalian dalam pengelolaan dan membantu manajemen dalam menghasilkan informasi yang terstruktur sehingga penjualan perusahaan berjalan dengan efektif.

Tercapainya efektivitas koletibilitas piutang tak tertagih dikarenakan beberapa faktor: (1) Pengelolaan order piutang mulai dari departemen penerimaan order sampai departemen penjualan sudah benar (2) Langkah yang benar pada pengolahan order dalam departemen penjualan, pemisahan order barang persediaan dari order barang pesanan, dan sebagainya (3) Langkah-langkah dalam persetujuan kredit pemisahan order yang akan diselesaikan, pemisahan orderuntuk berbagai pelanggan yang pantas diberi kredit (4) Prosedur yang benar dalam memproses order dari departemen kredit ke departemen pengiriman (5) Prosedur yang benar pada departemen pengiriman/penyerahan (6) Arus dokumen dari departemen pengiriman ke departemen pembuatan faktur sudah dicatat dengan prosedur yang baik (7) Transaksi dicatat tepat waktu dan diposting dengan benar melalui otorisasi yang jelas dari bagian yang berwenang dengan kelengkapan dokumen dari setiap transaksinya dicatat dengan benar

Tujuan penetapan kolektibilitas piutang adalah untuk mengetahui kualitas piutang sehingga bank dapat mengantisipasi risiko kredit secara dini karena risiko kredit dapat mempengaruhi kelangsungan usaha bank. Di samping itu, penetapan kolektibilitas piutang digunakan untuk menetapkan tingkat cadangan potensi kerugian akibat kredit bermasalah. Penetapan kualitas kredit mengacu pada ketentuan Bank Indonesia, yaitu PBI No.14/15/PBI/2012 tentang Penilaian Kualitas Aset Bank Umum dan SE BI No.7/3/DPN tanggal 31 Januari 2005 perihal Penilaian Kualitas Aktiva Bank Umum. Sesuai BI tersebut, kualitas piutang dapat ditentukan berdasarkan tiga parameter berikut: (a) Prospek Usaha (b) Kinerja Debitur (c) Kemampuan Membayar. Berdasarkan parameter tersebut, kualitas kredit ditetapkan menjadi Lancar, Dalam Perhatian Khusus, Kurang Lancar, Diragukan, dan Macet. Penetapan kualitas kredit tersebut dilakukan dengan mempertimbangkan materialitas dan signifikansi dari faktor penilaian dari komponen, serta relevansi dari faktor penilaian dan komponen tersebut terhadap karakteristik debitur yang bersangkutan.

\section{HIPOTESIS}

Hipotesis dalam penelitian ini adalah :

$\mathrm{H}_{0}$ : Tidak ada pengaruh sistem informasi akuntansi penjualan terhadap efektivitas pengendalian dan kolektabilitas piutang taktertagih pada BPRS Bhakti Sumekar cabang Pamekasan

$\mathrm{H}_{\mathrm{a}}$ : Ada pengaruh sistem informasi akuntansi penjualan terhadap efektivitas pengendalian dan kolektabilitas piutang taktertagih pada BPRS Bhakti Sumekar cabang Pamekasan

\section{METODOLOGI PENELITIAN}

Jenis penelitian ini menggunakan metode kuantitatif deskriptif dengan lokasi penelitian pada PT. BPRS Bhakti Sumekar Cabang Pamekasan. Pengambilan sampel dalam penelitian ini dilakukan dengan menggunakan teknik sampling jenuh. Hal ini dilakukan karena jumlah populasi relatif kecil, kurang dari 30 orang. Oleh karena itu,maka pengambilan sampelnya menggunakan Teknik Nonprobability Sampling dimana Nonprobability Sampling adalah teknik pengambilan sampel yang tidak memberi peluang/kesempatan sama bagi setiap unsur atau anggota populasi untukdipilih menjadi sampel. Adapun kriteria sampel adalah (1) Menjadi karyawan aktif di lembaga (2) Bekerja 
minimal 1 tahun (3) Bersedia dimintai keterangan. Penelitian ini menggunakan skala likert (Likert scale) sebagai skala pengukuran dan instrument yang digunakan dalam penelitian ini berupa kuesioner dan dokumentasi. Teknik analisis data yang digunakan adalah statistik deskriptif yang meliputi: (a) Uji kualitas data yang terdiri dari uji validitas dan uji reabilitas (b) Anlisis regresi sederhana (c) Pengujian hipotesa berupa uji parsial (uji t) dan analisa koefisien determinasi $\left(\mathrm{R}^{2}\right)$.

\section{HASIL DAN PEMBAHASAN}

\section{Analisis Deskriptif \\ Karakteristik Responden}

Penelitian ini menyebarkan 20 eksemplar kuesioner, kepada 20 karyawan BPRS Bhakti Sumekar Cabang Pamekasan. Dari 20 eksemplar kuesioner yang disebarkan, semuanya digunakan untuk diolah sebagai data primer karena sampel penelitian ini menggunakan sample jenuh yaitu teknik pengambilan sampel yang memberikan peluang yang sama bagi setiap unsur populasi untuk dipilih menjadi anggota sampel. Dikatakan simple random karena pengambilan anggota sampel dari populasi dilakukan secara acak tanpa memperhatikan strata yang ada dalam populasi. Berdasarkan 20 responden tersebut, berikut ini adalah rincian data responden berdasarkan variabel yang telah ditetapkan peneliti:

\section{Jenis Kelamin}

Terkait dengan data tentang jenis kelamin karyawan BPRS Bhakti Sumekar Cabang Pamekasan, yang menjadi responden pada penelitian ini yaitu sebagai berikut:

\section{Tabel 4. 1 Jenis Kelamin Responden}

\begin{tabular}{|l|c|c|c|c|}
\hline Jenis Kelamin & Frekuensi & Percent & Valid Percent & Cummulative Percent \\
\hline Laki-Laki & 19 & 95 & 95 & 95 \\
\hline Perempuan & 1 & 5 & 5 & 100,00 \\
\hline Total & 20 & 100 & 100 & \\
\hline
\end{tabular}

Sumber: Data primer diolah dengan menggunakan program SPSS versi 17.

Berdasarkan tabel tersebut, , untuk responden yang berjenis kelamin laki-laki berjumlah 19 orang dengan angka persentase sebesar 95\% dan untuk yang berjenis kelamin perempuan berjumlah 1 orang dengan angka persentase sebesar 5\%. Hal ini menandakan bahwa antara karyawan BPRS Bhakti Sumekar Cabang Pamekasan didominasi oleh karyawan laki-laki.

\section{Umur}

Terkait data tentang umur responden, peneliti mengklasifikasikannya menjadi 6 kategori, yaitu mulai dari di bawah $<20$ tahun, 21-30 tahun, 31-40 tahun, 41-50 tahun, 5160 tahun, dan >60 tahun ke atas. Berikut peneliti paparkan rincian umur responden yang telah berpartisipasi pada penelitian ini: 
Tabel 4. 2 Umur Responden

\begin{tabular}{|c|c|c|c|c|}
\hline Umur & Frekuensi & Percent & Valid Percent & Cummulative Percent \\
\hline $21-30$ & 5 & 25 & 25 & 25 \\
\hline $31-40$ & 11 & 55 & 55 & 100 \\
\hline $41-50$ & 4 & 20 & 20 & \\
\hline Total & 20 & 100 & 100 & \\
\hline
\end{tabular}

Sumber: Data primer diolah dengan menggunakan program SPSS versi 17.

Pada tabel tentang umur responden diatas, menunjukkan bahwa responden yang ikut berpartisipasi pada penelitian ini dengan kategori umur 21-30 sebanyak 5 responden sebesar 25\% dan 31-40 tahun dengan jumlah 11 responden sebesar 55\%, untuk responden yang berumur 41-50 tahun berjumlah 4 diperoleh angka persentase sebesar 20\%. Dengan kata lain, responden BPRS Bhakti Sumekar Cabang Pamekasan yangikut berpartisipasi pada penelitian ini berdasarkan kategori umur responden didominasi oleh responden yang berumur 31-40 tahun dengan angka persentase sebesar 55\%.

\section{Pendidikan Terakhir}

Data responden berdasarkan pendidikan terakhir responden diklasifikasikan menjadi 1 tingkatan saja, yaitu S1. Data tentang pendidikan terakhir responden yang diambil sebagai responden yaitu sebagai berikut:

Tabel 4. 3 Pendidikan Terakhir Responden

\begin{tabular}{|c|c|c|c|c|}
\hline Pendidikan Terakhir & Frequency & Percent & Valid Percent & Cummulative Percent \\
\hline S1 & 20 & 100,00 & 100,00 & 100,00 \\
\hline Total & 20 & 100 & 100 & \\
\hline
\end{tabular}

Sumber: Data primer diolah dengan menggunakan program SPSS versi 17.

Dilihat dari segi pendidikan terakhir responden, menyatakan bahwa dari ke 20 responden yang telah ikut berpartisipasi pada penelitian ini terdapat sebanyak 20 responden yang berpendidikan terakhir S1 dengan angka persentasenya sebesar 100,00\%.

\section{Deskriptif Variabel}

Analisis deskriptif bertujuan untuk mengetahui gambaran variabel-variabel yang dilihat dari nilai rata-rata (mean), standar deviasi, nilai maksimum dan nilai minimum. Yang diukur dalam penelitian meliputi sistem informasi akuntansi, efektifitas pengendalian piutang dan kolektabilitas piutang tak tertagih. Berikut paparan analisis deskriptif masingmasing variabel. 
Tabel 4. 4 Deskripsi statistik

\begin{tabular}{|c|c|c|c|c|c|}
\hline Variabel & $\mathrm{N}$ & Minimum & Maximum & Mean & Std. Deviation \\
\hline$X$ & 20 & 15 & 24 & 21.10 & 2.075 \\
\hline Y1 & 20 & 14 & 25 & 21.65 & 2.661 \\
\hline Y2 & 20 & 21 & 39 & 33.00 & 4.013 \\
\hline $\begin{array}{l}\text { Valid N } \\
\text { (listwise) }\end{array}$ & 20 & & & & \\
\hline
\end{tabular}

Sumber: Data Diolah Dengan SPSS 17, 2018

Berdasarkan tabel di atas, nilai $\mathrm{N}$ menunjukan jumlah sampel yang akan digunakan dalam penelitian ini yang berjumlah 20. Nilai minimum dari jumlah variabel sistem informasi akuntansi, efektivitas pengendalian piutang, dan kolektabilitas piutang tak tertagih bernilai 15,14 , dan 21 . Nilai maksimum dari jumlah variabel sistem informasi akuntansi, efektivitas pengendalian piutang, dan kolektabilitas piutang tak tertagih bernilai 24, 25 dan 39. Nilai mean jumlah variabel sistem informasi akuntansi, efektivitas pengendalian piutang, dan kolektabilitas piutang tak tertagihbernilai 21,10; 21,65 dan 33 . Sedangkan standar deviasi jumlah variabel sistem informasi akuntansi, efektivitas pengendalian piutang, dan kolektabilitas piutang tak tertagihbernilai2.075, 2.661 dan 4.013 .

\section{Analisis Data}

Instrumen dalam penelitian harus dapat dikatakan valid dan reliable, tujuannya untuk menguji apakah kuesioner layak atau tidak digunakan. Valid artinya data yang diperoleh melalui kuesioner dapat menjawab tujuan penelitian, sedangkan reliabel artinya data yang diperoleh melalui kuesioner hasilnya konsisten bila digunakan untuk peneliti lain. Berikut kriteria yang digunakan dalam uji kualitas data:

\section{Uji Validitas}

Validitas adalah suatu derajad ketepatan instrumen (alat ukur). Maksudnya apakah instrumen yang digunakan betul-betul tepat untuk mengukur apa yang akan di ukur. Uji validitas dilakukan untuk mengukur valid atau tidaknya suatu item pertanyaaan dan mampu mengungkapkan apa yang seharusnya diukur dari Pearson Correlation. Pada pengujian validitas ini dapat dilakukan denganmenghitung korelasi antara skor butir pertanyaan dengan total skor konstruk.

Tingkat validitas uji signifikansi dengan membandingkan $r_{\text {hitung }}$ dengan $r_{\text {tabel }}\left(r_{\text {hitung }}>r_{\text {tabel }}\right)$. Pada penelitian ini, dengan $\mathrm{N}=20$ responden dan $a=0,05$ (5\%) yang digunakan, diperoleh $r_{\text {tabel }}$ sebesar 0,4227 . Item pertanyaan yang ditemukan tidak valid dalam uji validitas tidak diikut sertakan dalam pengujian selanjutnya. Uji validitas kali ini menggunakan program SPSS versi 17, seluruh item pertanyaan pada variabel $X$ (sistem informasi akuntansi), variabel $\mathrm{Y}_{1}$ (efektivitas pengendalian piutang), dan variabel $\mathrm{Y}_{2}$ (kolektabilitas piutang tak tertagih) dapat dikatakan valid jika memiliki nilai koefisien korelasi $>0,4227$ ( $t_{\text {hitung }}>r_{\text {tabel }}$ ). Berikut ini adalah hasil dari uji validitas per item pertanyaan terhadap skor totalnya: 
Tabel 4. 5Uji Validitas

\begin{tabular}{|c|c|c|c|c|c|}
\hline Variabel & $\begin{array}{l}\text { Item } \\
\text { Pertanyaan }\end{array}$ & $\begin{array}{c}\text { Koefisien } \\
\text { Korelasi } \\
\left(\mathrm{r}_{\text {hitung }}\right)\end{array}$ & $r_{\text {tabel }}$ & Keterangan & Indikator \\
\hline \multirow{5}{*}{$\begin{array}{c}\text { Sistem } \\
\text { informasi } \\
\text { akuntansi } \\
\text { (X) }\end{array}$} & $\mathrm{X} 1$ & 0,710 & 0,4227 & Valid & SDM dan alat \\
\hline & $\mathrm{X} 2$ & 0,805 & 0,4227 & Valid & \\
\hline & $\mathrm{X} 3$ & 0,632 & 0,4227 & Valid & \\
\hline & $\mathrm{X} 4$ & 0,817 & 0,4227 & Valid & $\begin{array}{l}\text { Data formulir atau } \\
\text { catatan }\end{array}$ \\
\hline & $\mathrm{X} 5$ & 0,639 & 0,4227 & Valid & Kualita informasi \\
\hline \multirow{5}{*}{$\begin{array}{c}\text { Efektivita } \\
\text { s } \\
\text { Pengendal } \\
\text { ian } \\
\text { Piutang } \\
\text { (Y1) }\end{array}$} & Y1_1 & 0,845 & 0,4227 & Valid & $\begin{array}{l}\text { Menyediakan data } \\
\text { yang dapat di } \\
\text { percaya }\end{array}$ \\
\hline & Y1_2 & 0,731 & 0,4227 & Valid & \\
\hline & Y1_3 & 0,839 & 0,4227 & Valid & $\begin{array}{l}\text { Melindungi harta } \\
\text { dan catatan } \\
\text { perusahaan }\end{array}$ \\
\hline & Y1_4 & 0,869 & 0,4227 & Valid & \\
\hline & Y1_5 & 0,705 & 0,4227 & Valid & \\
\hline \multirow{4}{*}{$\begin{array}{l}\text { Kolektabil } \\
\text { itas } \\
\text { Piutang }\end{array}$} & Y2_1 & 0,787 & 0,4227 & Valid & $\begin{array}{l}\text { Pemeriksaan } \\
\text { umur piutang }\end{array}$ \\
\hline & Y2_2 & 0,849 & 0,4227 & Valid & \\
\hline & Y2_3 & 0,899 & 0,4227 & Valid & \\
\hline & Y2_4 & 0,715 & 0,4227 & Valid & \\
\hline \multirow{4}{*}{$\begin{array}{l}\text { Tak } \\
\text { tertagih } \\
(Y 2)\end{array}$} & Y2_5 & 0,665 & 0,4227 & Valid & \\
\hline & Y2_6 & 0,573 & 0,4227 & Valid & \\
\hline & Y2_7 & 0,726 & 0,4227 & Valid & \\
\hline & Y2_8 & 0,766 & 0,4227 & Valid & \\
\hline
\end{tabular}

Berdasarkan tabel tersebut, dapat diketahui bahwa nilai $\mathbf{r}_{\text {hitung }}$ pada kolom koefisien korelasi untuk tiap item pertanyaan memiliki $\mathrm{r}_{\text {hitung }}$ yang lebih besar dan positif dibandingkan dengan $r_{\text {tabel }}$ yaitu 0,4227 dengan jumlah sampel adalah 20 responden $(\mathrm{N}=20)$ dan $a=0,05$. Sehingga dapat ditarik kesimpulan bahwa semua item pertanyaan dari variabel $\mathrm{X}$ (sistem informasi akuntansi), variabel $\mathrm{Y} 1$ (efektivitas pengendalian piutang) dan variabel Y2 (kolektabilitas piutang tak tertagih) adalah valid dan dapat dilanjutkan dengan tahap pengujian berikutnya. 


\section{Uji Reliabilitas}

Suatu instrumen dikatakan reliable (andal) jika jawaban seorang responden terhadap pertanyaan adalah konsisten atau stabil dari waktu kewaktu. Uji reliabilitas bertujuan untuk mengetahui konsistensi jawaban responden atas kuesioner yang telah diberikan. Bukti kuesioner dikatakan reliabel atau andal apabila jawaban responden terhadap kuesioner adalah konsisten dengan memiliki nilai Cronbach's Alpha $\geq 0,60$. Pada pengujian reliabilitas penelitian ini peneliti menggunakan aplikasi SPSS (Statistical Package for The Social Sciences) versi 17 untuk mengetahui hasil dari uji reliabilitas. Hasil uji reliabilitas instrumen pada penelitian ini yaitu sebagai berikut:

Tabel 4. 6 Reliabilitas Efektivitas Pengendalian Piutang

\begin{tabular}{|c|c|c|}
\hline Variabel & Cronbach's Alpha & Keterangan \\
\hline Sistem Informasi Akuntansi & 0,769 & Reliabel \\
\hline $\begin{array}{c}\text { Efektivitas Pengendalian } \\
\text { Piutang }\end{array}$ & 0,858 & Reliabel \\
\hline $\begin{array}{c}\text { Kolektabilitas piutang tak } \\
\text { tertagih }\end{array}$ & 0,883 & Reliabel \\
\hline
\end{tabular}

Berdasarkan tabel uji reabilitas tersebut, menunjukkan bahwa masing-masing item tiap variabel memiliki nilai Cronbach's Alpha $\geq 0,60(a>0,60)$, sehingga hal ini dapat dikatakan bahwa variabel $\mathrm{X}$ (sistem informasi akuntansi), variabel $\mathrm{Y}_{1}$ (efektivitas pengendaalian piutang) dan variabel $\mathrm{Y}_{2}$ (kolektabilitas oiutang tak tertagih) adalah reliabel.

\section{Pembuktian Hipotesis}

\section{AnalisisRegresi Linier Sederhana}

Pada penelitian ini, metode analisis statistik yang digunakan adalah metode analisis statistik regresi linier sederhana karena terdapat dua variabel yakni sistem informasi akuntani (variabel bebas) dan efektivitas pengendalan piutang dan kolektabilitas piutang tak tertagih (variabel terikat). Analisis regresi sederhana untuk mengetahui pengaruh variabel bebas (sistem informasi akuntansi) terhadap variabel terikat (efektivitas pengendalan piutang dan kolektabilitas piutang tak tertagih) atas perubahan dari setiap peningkatan atau penurunan variabel bebas yang akan mempengaruhi variabel terikat. Model regresi linier sederhana dengan persamaan sebagai berikut:

$$
\begin{aligned}
& \mathrm{Y}_{1}=\alpha+\mathrm{bX}+\mathrm{e} \\
& \mathrm{Y}_{2}=\alpha+\mathrm{bX}+\mathrm{e}
\end{aligned}
$$

dimana:

- $\mathrm{Y}_{1}=$ Variabel terikat (efektivitas pengendalian piutang)

- $\mathrm{Y}_{2} \quad=$ Variabel terikat (kolektabilitas piutang tak tertagih)

- $\alpha=$ Konstanta

- $\mathrm{b}=$ Koefisien regresi

- $\mathrm{X}=$ Variabel bebas (sistem informasi akuntansi)

- $\mathrm{e}=$ komponen sisaan yang tidak diketahui hasilnya 
Berdasarkan hasil pengolahan data dapat dihasilkan sebagai berikut:

Tabel 4. 7 Coefficients ${ }^{\mathrm{a}}$ efektivitas

\begin{tabular}{|rr|r|r|r|r|r|}
\hline \multirow{2}{*}{ Model } & \multicolumn{2}{|c|}{$\begin{array}{c}\text { Unstandardized } \\
\text { Coefficients }\end{array}$} & $\begin{array}{c}\text { Standardized } \\
\text { Coefficients }\end{array}$ & & \\
\cline { 2 - 5 } & \multicolumn{1}{|c|}{$\mathrm{B}$} & Std. Error & \multicolumn{1}{c|}{ Beta } & \multicolumn{1}{c|}{$\mathrm{T}$} & \multicolumn{1}{c|}{ Sig. } \\
\hline 1 & (Constant) & -.714 & 3.608 & & -.198 & .845 \\
& & 1.060 & .170 & .826 & 6.227 & .000 \\
\hline
\end{tabular}

a. Dependent Variable: Y1

Berdasarkan hasil perhitungan dengan menggunakan analisa regresi linier dengan menggunakan bantuan program SPSS maka dapat dibuat model persamaan regresi linear untuk efektivitas pengendalian piutang sebagai berikut:

$$
\mathrm{Y}_{1}=-0,714+1,060 \mathrm{X}
$$

Dari persamaan linier regresi sederhana tersebut di atas, dapat diartikan sebagai berikut :

\section{a. Constant $=-\mathbf{0 , 7 1 4}$}

Artinya; jika faktor sistem informasi akuntansi dianggap constant/tetap $(X=0)$, maka ada kontribusi negatif / berkurang terhadap faktor efektifitas pengendalian piutang sebesar 0,714 satuan.

\section{b. + 1,060 X (Faktor Sistem Informasi Akuntasi)}

Artinya; jika faktor sistem informasi akuntansidapat ditingkatkan sebesar satu satuan yang ada pada saat ini; maka ada kontribusi positif / bertambah terhadap faktor efektivitas pengendalian piutang sebesar 1,060.

\section{Tabel 4. 8 Coefficients ${ }^{\mathrm{a}}$ kolektabilitas}

\begin{tabular}{|c|c|c|c|c|c|}
\hline \multirow[b]{2}{*}{ Model } & \multicolumn{2}{|c|}{$\begin{array}{l}\text { Unstandardized } \\
\text { Coefficients }\end{array}$} & \multirow{2}{*}{\begin{tabular}{|c|}
$\begin{array}{c}\text { Standardized } \\
\text { Coefficients }\end{array}$ \\
Beta
\end{tabular}} & \multirow[b]{2}{*}{$\mathrm{T}$} & \multirow[b]{2}{*}{ Sig. } \\
\hline & B & Std. Error & & & \\
\hline (Constant) & -1.565 & 5.137 & & -.305 & .764 \\
\hline$X$ & 1.638 & .242 & .847 & 6.759 & .000 \\
\hline
\end{tabular}

a. Dependent Variable: Y2

Berdasarkan hasil perhitungan dengan menggunakan analisa regresi linier dengan menggunakan bantuan program SPSS maka dapat dibuat model persamaan regresi linear untuk kolektabilitas piutang tak tertagih sebagai berikut:

$$
\mathrm{Y}_{2}=-1,565+1,638 \mathrm{X}
$$

Dari persamaan linier regresi sederhana tersebut di atas, dapat diartikan sebagai berikut : 
a. Constant $=-\mathbf{- 1 , 5 6 5}$

Artinya; jika faktor sistem informasi akuntansi dianggap constant/tetap ( $X=0)$, maka ada kontribusi negatif / berkurang terhadap faktor kolektabilitas piutang tak tertagih sebesar 1,565 satuan.

\section{b. + 1,638 X (Faktor Sistem Informasi Akuntasi)}

Artinya; jika faktor sistem informasi akuntanis dapat ditingkatkan sebesar satu satuan yang ada pada saat ini; maka ada kontribusi positif / bertambah terhadap faktor kolektabilitas piutang tak tertagih sebesar 1,638.

\section{Uji -t (Uji individual/Parsial)}

Uji-t dilakukan untuk mengetahui adakah pengaruh antara variabel $\mathrm{X}$ (sistem informasi akuntansi)dengan variabel $\mathrm{Y}_{1}$ (efektivitas pengendalian piutang) dan variabel $\mathrm{Y}_{2}$ (kolektabilitas piutang tak tertagih) dengan $a=0,05$. Uji $\mathrm{t}$ dilakukan dengan membandingkan antara nilai signifikansi dengan taraf alpha 0,05. Jika nilai sig lebih kecil dari alpha 0,05 $(\mathrm{sig}<0,05)$ maka Ho ditolak dan Ha diterima. Artinya sistem informasi akuntansi berpengaruh terhadap efektifitas pengendalian piutang dan kolektabilitas piutang tak tertagih. Sebaliknya jika nilai sig lebih besar dari alpha 0,05 (sig>0,05) maka Ho diterima dan Ha ditolak. Artinya sistem informasi akuntansi tidak berpengaruh terhadap efektifitas pengendalian piutang dan kolektabilitas piutang tak tertagih.Berikut hasil Uji-t dengan menggunakan SPSS versi 17:

Tabel 4. 9 Hasil Uji-t Efektivitas

\begin{tabular}{|c|c|c|c|c|c|c|}
\hline \multirow{2}{*}{\multicolumn{2}{|c|}{ Model }} & \multicolumn{2}{|c|}{$\begin{array}{l}\text { Unstandardized } \\
\text { Coefficients }\end{array}$} & \multirow{2}{*}{$\begin{array}{c}\text { Standardized } \\
\text { Coefficients }\end{array}$} & \multirow[b]{2}{*}{$\mathrm{T}$} & \multirow[b]{2}{*}{ Sig. } \\
\hline & & B & Std. Error & & & \\
\hline \multirow[t]{2}{*}{1} & (Constant) & -.714 & 3.608 & & -.198 & .845 \\
\hline & $X$ & 1.060 & .170 & .826 & 6.227 & .000 \\
\hline
\end{tabular}

a. Dependent Variable: Y1

Dari tabel 4.9 diatas dapat diketahui bahwa nilai signifikansi dari variabel X (sistem informasi akuntansi) adalah 0,000 dibawah $0,05(<0,05)$. Hal ini dapat disimpulkan dari tabel diatas bahwa efektivitas pengendalian piutang dipengaruhi oleh sistem informasi akuntansi (SIA). 
Tabel 4. 10 Hasil Uji-tKolektabilitas

\begin{tabular}{|rr|r|r|r|r|r|}
\hline \multirow{2}{*}{ Model } & \multicolumn{2}{|c|}{$\begin{array}{c}\text { Unstandardized } \\
\text { Coefficients }\end{array}$} & $\begin{array}{c}\text { Standardized } \\
\text { Coefficients }\end{array}$ & & \\
\cline { 2 - 5 } & \multicolumn{1}{|c|}{$\mathrm{B}$} & Std. Error & \multicolumn{1}{c|}{ Beta } & \multicolumn{1}{c|}{$\mathrm{T}$} & \multicolumn{1}{c|}{ Sig. } \\
\hline 1 & (Constant) & -1.565 & 5.137 & & -.305 & .764 \\
& $\mathrm{X}$ & 1.638 & .242 & .847 & 6.759 & .000 \\
\hline
\end{tabular}

a. Dependent Variable: Y2

Sumber: Data primer diolah dengan SPSS 17, 2018

Dari tabel 4.10 diatas dapat diketahui bahwa nilai signifikansi dari variabel $\mathrm{X}$ (sistem informasi akuntansi) adalah 0,000 dibawah 0,05 $(<0,05)$. Hal ini dapat disimpulkan dari tabel diatas bahwa kolektabilitas piutang tak tertagih dipengaruhi oleh sistem informasi akuntansi (SIA).

\section{Menghitung Data Dengan Melakukan Uji Koefisien Korelasi}

Dalam penelitian ini model persamaan korelasi Pearson yang disusun untuk mengetahui pengaruh sistem informasi akuntansi terhadap efektivitas pengendalian piutang dan kolektabilitas piutang tak tertagih di BPRS Bhakti Sumekar Pamekasan.

Peneliti menggunakan program SPSS (Statistical Package for The Social Sciences) versi 17 untuk menganalisis data. Dari hasil analisis menggunakan program SPSS versi 17 ini, diperoleh hasil analisis sebagai berikut:

Tabel 4. 11Uji Korelasi Variabel Sistem Informasi Akuntansi (X) dengan Efektivitas Pengendalian Piutang (Y1)

\begin{tabular}{|rl|r|r|}
\hline & & \multicolumn{1}{|c|}{ X } & \multicolumn{1}{c|}{ Y1 } \\
\hline $\mathrm{X}$ & Pearson & 1 & $.826^{* *}$ \\
& Correlation & & \\
& Sig. (2-tailed) & & .000 \\
& $\mathrm{~N}$ & 20 & 20 \\
\hline $\mathrm{Y} 1 \quad$ Pearson & $.826^{* *}$ & 1 \\
& Correlation & & \\
& Sig. (2-tailed) & .000 & \\
& $\mathrm{~N}$ & 20 & 20 \\
\hline
\end{tabular}

**. Correlation is significant at the 0.01 level (2-tailed). 
Berdasarkan hasil analisis korelasi pada tabel tersebut, dapat di interpretasikan bahwa: (1) Angka korelasi antara sistem informasi akuntansi dengan efektivitas pengendalian piutang diperoleh harga koefisien sebesar 0,826 untuk efektifitas pengendalian piutang dengan signifikansi $0,000<0,05$, maka H0 ditolak. Hal ini menunjukkan bahwa hubungan korelasi sebesar 0,826 signifikan (2) Berdasarkan data tersebut, maka dapat dilakukan pengujian hipotesis dengan membandingkan taraf signifikansinya yaitu: (1) Jika signifikansi >0,05, maka Ho diterima (2) Jika signifikansi $<0,05$, maka Ho ditolak (3) Keputusan: Setelah melakukan analisis data dengan menggunakan uji Korelasi Pearson (Product Moment) tersebut, maka dapat diketahui bahwa signifikansi variabel sistem informasi akuntansi 0,000 , karena signifikansi $<0,05$ maka Ho ditolak. Jadi ada hubungan yang signifikan antara sistem informasi akuntansi dengan efektivitas pengendalian piutang (4) Tolak Ukur Pengujian: Jika $r_{\text {hitung }}>r_{\text {tabel }}$, maka Ho ditolak, Jika $r_{\text {hitung }}<r_{\text {tabel}}$, maka Ho diterima

Tabel 4. 12Uji Korelasi Variabel Sistem Informasi Akuntansi (X) dengan Kolektabilitas Piutang Tak Tertagih (Y)

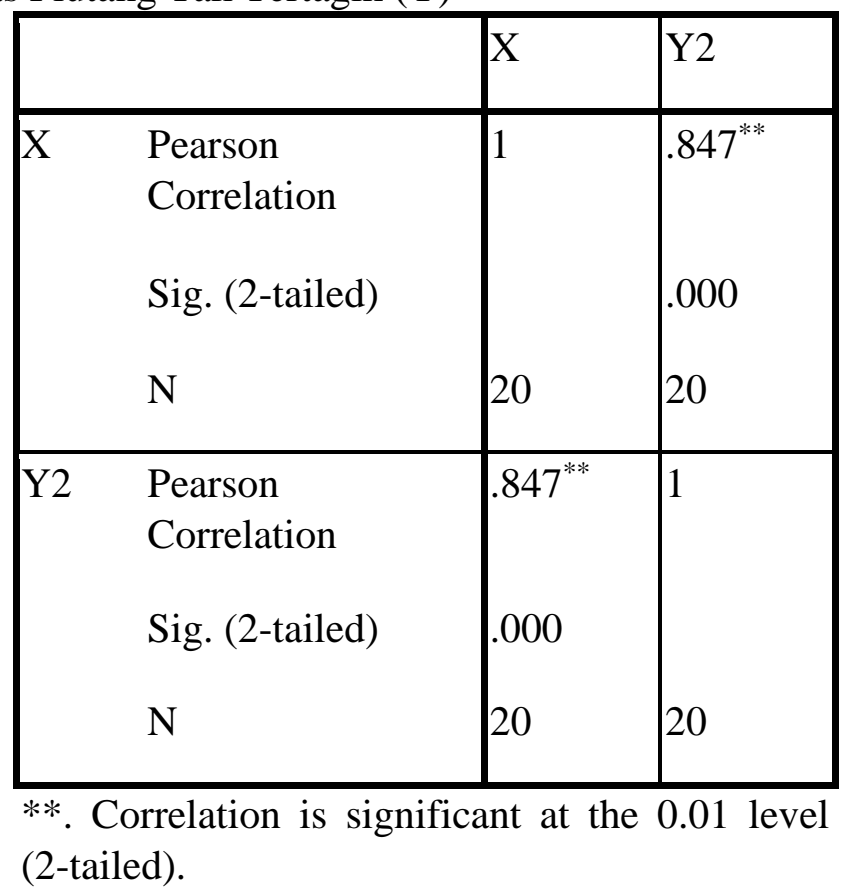

Berdasarkan hasil analisis korelasi pada tabel tersebut, dapat di interpretasikan bahwa: (1) Angka korelasi antara sistem informasi akuntansi dengan kolektabilitas piutang tak tertagih koefisien sebesar 0,847 untuk kolektabilitas piutang tak tertagih dengan signifikansi $0,000<0,05$, maka H0 ditolak. Hal ini menunjukkan bahwa hubungan korelasi sebesar 0,847 signifikan (2) Berdasarkan data tersebut, maka dapat dilakukan pengujian hipotesis dengan membandingkan taraf signifikansinya yaitu: (1) Jika signifikansi >0,05, maka Ho diterima (2) Jika signifikansi <0,05, maka Ho ditolak (3) Keputusan: Setelah melakukan analisis data dengan menggunakan uji Korelasi Pearson (Product Moment) tersebut, maka dapat diketahui bahwa signifikansi variabel sistem informasi akuntansi 0,000, karena signifikansi $<0,05$ maka Ho ditolak. Jadi ada hubungan yang signifikan antara sistem informasi akuntansi dengan kolektabilitas piutang tak tertagih (4) Tolak Ukur Pengujian: Jika $r_{\text {hitung }}>r_{\text {tabel }}$, maka Ho ditolak, Jika $\mathrm{r}_{\text {hitung }}<\mathrm{r}_{\text {tabel }}$, maka Ho diterima. 


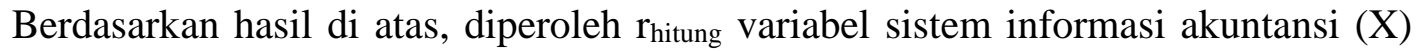
untuk efektivitas pengendalian piutang sebesar 0,826 dan variabel sistem informasi akuntansi (X) sebesar 0,847 untuk kolektabilitas piutang tak tertagih. Maka berdasarkan $\mathrm{r}_{\text {tabel }}$ dengan taraf kepercayaan 0,05 ( $\mathrm{r}_{\text {tabel }}$ untuk 20 subjek dengan taraf kepercayaan 5\% adalah 0,4227), hal ini menunjukkan bahwa $r_{\text {hitung }}>r_{\text {tabel }}$ maka Ho ditolak. Dengan demikian, terdapat hubungan yang signifikan antara sistem informasi akuntansi dengan efektivitas pengendalian piutang dan kolektabilitas piutang tak tertagih. Berdasarkan hasil korelasi bernilai positif yang diperolehkan tersebut, menunjukkan bahwa semakin baik sistem informasi akuntansi maka akan semakin baik efektivitas pengendalian piutang dan kolektabilitas piutang tak tertagih.

\section{Koefisien Korelasi Sederhana (R)}

Variable X mempunyai hubungan yang erat dengan variabel $\mathrm{Y}$. artinya setiap perubahan dari nilai $\mathrm{X}$ akan memberikan pengaruh pada variable $\mathrm{Y}$. hal dapat diketahui dari nilai koefisien korelasi sederhana (R). Nilai koefisien korelasi sederhana menunjukkan seberapa erat hubungan antara variabel X (variabel input) dengan variabel Y (variabel output).

Tabel 4. 13 Korelasi Efektivitas Pengendalian Piutang Model Summary ${ }^{b}$

\begin{tabular}{|l|r|r|r|r|r|}
\hline Model & \multicolumn{1}{|c|}{$\mathrm{R}$} & R Square & $\begin{array}{c}\text { Adjusted R } \\
\text { Square }\end{array}$ & $\begin{array}{c}\text { Std. Error of } \\
\text { the Estimate }\end{array}$ & $\begin{array}{c}\text { Durbin- } \\
\text { Watson }\end{array}$ \\
\hline 1 & $.826^{\mathrm{a}}$ & .683 & .665 & 1.539 & 2.294 \\
\hline
\end{tabular}

a. Predictors: (Constant), $\mathrm{X}$

b. Dependent Variable: Y1

Berdasarkan hasil pengolahan data dengan menggunakan bantuan program SPSS diperoleh hasil besarnya nilai koefisien korelasi sederhana (R) untuk efektivitas pengendalian piutang sebesar 0,826 artinya bahwa variabel input yang terdiri sistem informasi akuntansi (X) mempunyai Shubungan yang erat atau kuat terhadap efektivitas pengendalian piutang (variabel Y) yaitu sebesar 0,826 atau 82,6\%.

Tabel 4. 14Korelasi Kolektabilitas Piutang Tak Tertagih

\begin{tabular}{|l|r|r|r|r|r|}
\hline Model & \multicolumn{1}{|c|}{ R } & R Square & $\begin{array}{c}\text { Adjusted R } \\
\text { Square }\end{array}$ & $\begin{array}{l}\text { Std. Error of } \\
\text { the Estimate }\end{array}$ & $\begin{array}{c}\text { Durbin- } \\
\text { Watson }\end{array}$ \\
\hline 1 & $.847^{\mathrm{a}}$ & .717 & .702 & 2.192 & 2.551 \\
\hline
\end{tabular}
a. Predictors: (Constant), X
b. Dependent Variable: Y2

Berdasarkan hasil pengolahan data dengan menggunakan bantuan program SPSS diperoleh hasil besarnya nilai koefisien korelasi sederhana $(\mathrm{R})$ untuk kolektabilitas piutang tak tertagih sebesar 0,847 artinya bahwa variabel input yang terdiri sistem informasi 
akuntansi (X) mempunyai hubungan yang erat atau kuat terhadap kolektabilitas piutang tak tertagih (variabel Y) yaitu sebesar 0,847 atau 84,7\%.

\section{Koefisien Determinasi $\left(\mathbf{R}^{2}\right)$}

Nilai koefisien determinasi atau $\left(\mathrm{R}^{2}\right)$ untuk mengukur seberapa jauh kemampuan model dalam menerangkan variasi variabel terikat. Hasil perhitungan untuk efektivitas pengendalian piutang diperoleh nilai $\left(\mathrm{R}^{2}\right)=0,683$ yang berarti bahwa 68,3\% efektifitas pengendalian piutang dapat dijelaskan oleh sistem informasi akuntansi (X). Sedangkan sisanya 31,7 \% dipengaruhi oleh variabel lain diluar model yang diteliti.

Hasil perhitungan untuk kolektabilitas piutang tak tertagih diperoleh nilai $\left(\mathrm{R}^{2}\right)=$ 0,717 yang berarti bahwa 71,7 \% kolektabilitas piutang tak tertagih dapat dijelaskan oleh sistem informasi akuntansi (X). Sedangkan sisanya $28,3 \%$ dipengaruhi oleh variabel lain diluar model yang diteliti.

\section{Kesimpulan}

Berdasarkan apa yang telah di jelaskan sebelumnya, yakni hasil analisis datadan pengujian hipotesis yang telah dilakukan, maka dapat di tarik sebuah kesimpulan bahwa (1) Sistem informasi akuntansi berpengaruh terhadap efektivitas pengendalian piutang dan kolektabilitas piutang tak tertagih (2) Dari hasil uji-t diketahui bahwa nilai signifikansi variabel $\mathrm{X}$ adalah 0,000 dibawah $0,05(<0,05)$. Hal ini dapat disimpulkan bahwa sistem informasi akuntansi berpengaruh terhadap efektivitas pengendalian piutang dan kolektabilitas piutang tak tertagih.Nilai tersebut membuktikan bahwa $\mathrm{H}_{\mathrm{o}}$ ditolak dan $\mathrm{H}_{\mathrm{a}}$ diterima. Artinya ada pengaruh positif dan signifikan dari variabelsistem informasi akuntansi terhadap efektivitas pengendalian piutang dan kolektabilitas piutang tak tertagih BPRS Bhakti Sumekar (3) Nilai koefisien korelasi sederhana (R) untuk efektivitas pengendalian piutang sebesar 0,826 artinya bahwa variabel input yang terdiri sistem informasi akuntansi (X) mempunyai hubungan yang erat atau kuat terhadap efektivitas pengendalian piutang (variabel Y) yaitu sebesar 0,826 atau 82,6\% (4) Nilai koefisien korelasi sederhana $(\mathrm{R})$ untuk kolektabilitas piutang tak tertagih sebesar 0,847 artinya bahwa variabel input yang terdiri sistem informasi akuntansi (X) mempunyai hubungan yang erat atau kuat terhadap kolektabilitas piutang tak tertagih (variabel Y) yaitu sebesar 0,847 atau $84,7 \%$ (5) Nilai koefisien determinasi atau $\left(\mathrm{R}^{2}\right)$ untuk mengukur seberapa jauh kemampuan model dalam menerangkan variasi variabel terikat. Hasil perhitungan untuk efektivitas pengendalian piutang diperoleh nilai $\left(\mathrm{R}^{2}\right)=0,683$ yang berarti bahwa 68,3\% efektifitas pengendalian piutang dapat dijelaskan oleh sistem informasi akuntansi (X). Sedangkan sisanya $31,7 \%$ dipengaruhi oleh variabel lain diluar model yang diteliti (6) Hasil perhitungan untuk kolektabilitas piutang tak tertagih diperoleh nilai $\left(R^{2}\right)=0,717$ yang berarti bahwa 71,7 \% kolektabilitas piutang tak tertagih dapat dijelaskan oleh sistem informasi akuntansi (X). Sedangkan sisanya 28,3\% dipengaruhi oleh variabel lain diluar model yang diteliti. 


\section{DAFTAR PUSTAKA}

Alvin, A. Arens, 2007, Auditing dan Pelayanan Verifikasi Jilid 1 : PendekatanTerpadu, dialih bahasakan oleh Tim Dejacarta, Edisi 9, Indeks : Jakarta.

Andreas. 2006. Analisis Sistem Informasi Akuntansi Penjualan TerhadapPenurunan Tingkat Piutang TakTertagih. Skripsi

Aryanto,Mahatmyo. 2014. Sistem Informasi Akuntansi Suatu Pengantar, Deepublish, yogyakarta

Christian, Victoria. 2015. Analisis Pengendalian Interna Piutang Usaha Pada Developer Grand Kawanua International City. Jurnal EMBA Vol. 3 No.1 Maret 2015, Hal. 286-296

Dr. La Midjan dan Azhar Susanto, 2001. Sistem Informasi Akuntansi I Edisi 8, Lingga Jaya, Bandung

Fakhri M. Husein, 2004, Sistem Informasi Akuntansi, Edisi Pertama: Jogjakarta

Fiqih, Abdul. 2010. "Analisis Faktor-Faktor yang Mempengaruhi Realisasi Penerimaan Pendapatan Asli Daerah (PAD) Kota Tanggerang pada tahun 2004-2008", Skripsi UIN Syarif Hidayatullah Jakarta

Haryono, jusup, 2011, Dasar-dasar Akuntansi, sekolah tinggi ekonomi YKPN, Yogyakarta.

Idrus, Muhammad.MetodePenelitianIlmu Sosial Pendekatan Kualitatif dan Kuantitatif, (Jakarta: Erlangga), hlm., 100

Ikatan Akuntansi Indonesia, 2002, Standar Akuntansi Keuangan, Salemba Empat :Jakarta.

Ismail, Akuntansi Bank, Prenamedia Group, Rawamangun, Jakarta

Jogiyanto. 2005. Analisis dan Desain Sistem Informasi. Yogyakarta: Penerbit Andi.

Maulana Robi, 2016. Pengaruh Sistem Informasi Akuntansi Penjualan Terhadap Efektivitas Kolektibilitas Piutang Tak Tertagih Pada PT Colombus Showroom Majalengka. Jurnal Ilmiah Manajemen \& Akuntansi Vol. 3. ISSN: 2356-3293

Moermahadi Soerja Djanegara dan Livia Ivonia. 2006. Evaluasi Pengendalian InternPenjualanKredit DalamMeningkatkanKolektibilitas PiutangpadaPT Austindo Nusantara Jaya Finance, Jurnal Umum

Mulyadi, 2001, Sistem Akuntansi : Sistem Penerimaan Kas, Edisi Empat :Jakarta

Mulyadi, 2004, Pemeriksaan Akuntansi, Edisi Ketiga, Yogyakarta, Penerbit Sekolah Tinggi Ekonomi YKPN.

Rahmawati Suci, 2015. Pengaruh Sistem Informasi Akuntansi Penjualan Terhadap Efektivitas Pengendalian Piutang Pada PT. Permata Finance Samarinda. Jurnal Universitas 17 Agustus 1945 Samarinda, Kalimatan Timur

Sugiyono. 2008. Metode Penelitian Bisnis. Bandung : CV. Alfabeta 
Sugiri, Slamet dan Bogat Agus Riyono. 2008. Akuntansi Pengantar 1.Yogyakarta: STIM

Sumarsan, Thomas. 2013, Perpajakan Indonesia (Vol.3), Jakarta: PT Index

Rudianto, 2012, Pengantar Akuntansi, Jakarta, Penerbit Erlangga Adaptasi IFRS.

Stoner, James A.F, 2001. Managemen, Terjemahan Alfansus Sirait, Jilid I, Edisi kedua, Penerbit Erlangga, Jakarta.

Susanto, Azhar. 2004, Sistem Informasi Akuntansi I :Pendekatan Manual PratikaPenyusunan Metode dan Prosedur Edisi Kedelapan :Bandung

Swastha, Basu, 2000, Pengantar Bisnis Modern, Pengantar Ekonomi Perusahaan Modern, Jakarta : Liberty.

Sugiyono, 2006, Statistika untuk Penelitian, Alfabeta : Bandung

Sugiyono, 2014. "Metode Penelitian Kuantitatif Kualitatif dan R\&D”, Alfabeta, Bandung.

Sunarto., 2003, Akuntansi Biaya, Edisi Revisi, AMUS, Yogyakarta

Wilkinson, Joseph W, 2000, Accounting Information System, Fourth Edison, yang dialih bahasakan oleh Agus Maulana : Jakarta 